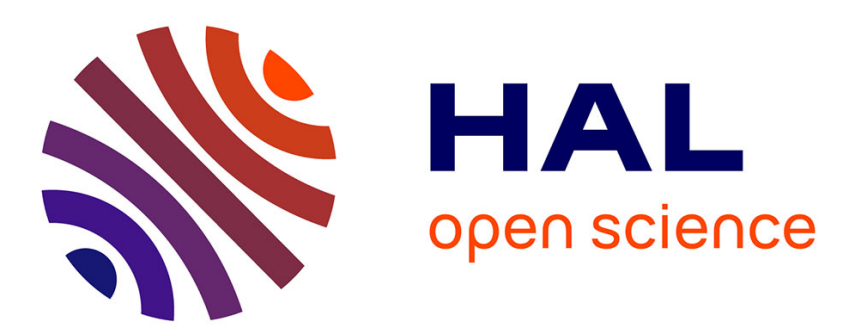

\title{
Preparation and Properties of Sodium \\ Dimethyldithioarsinate Dihydrate, Me2AsS2Na 2H2O, and Palladium(II) Dimethyldithioarsinate, (Me2AsS2)2Pd
}

Panayiotis V Ioannou

\section{To cite this version:}

Panayiotis V Ioannou. Preparation and Properties of Sodium Dimethyldithioarsinate Dihydrate, Me2AsS2Na 2H2O, and Palladium(II) Dimethyldithioarsinate, (Me2AsS2)2Pd. Journal of Inorganic and General Chemistry / Zeitschrift für anorganische und allgemeine Chemie, 2009, 635 (13-14), pp.2203. 10.1002/zaac.200900173 . hal-00502867

\section{HAL Id: hal-00502867 https://hal.science/hal-00502867}

Submitted on 16 Jul 2010

HAL is a multi-disciplinary open access archive for the deposit and dissemination of scientific research documents, whether they are published or not. The documents may come from teaching and research institutions in France or abroad, or from public or private research centers.
L'archive ouverte pluridisciplinaire HAL, est destinée au dépôt et à la diffusion de documents scientifiques de niveau recherche, publiés ou non, émanant des établissements d'enseignement et de recherche français ou étrangers, des laboratoires publics ou privés. 


\section{Preparation and Properties of Sodium Dimethyldithioarsinate Dihydrate, Me2AsS2Na.2H2O, and Palladium(II) Dimethyldithioarsinate, (Me2AsS2)2Pd}

\begin{tabular}{|r|l|}
\hline Journal: & Zeitschrift für Anorganische und Allgemeine Chemie \\
\hline Manuscript ID: & zaac. 200900173 \\
\hline Wiley - Manuscript type: & Article \\
\hline Date Submitted by the \\
Author: & 26-Mar-2009 \\
\hline Complete List of Authors: & Ioannou, Panayiotis; University of Patras, Chemistry \\
\hline Keywords: & Sodium dimethyldithioarsinate, Palladium(II) dimethyldithioarsinate \\
\hline
\end{tabular}

\section{$x$}




\section{Preparation and Properties of}

\section{Sodium Dimethyldithioarsinate Dihydrate, $\mathrm{Me}_{2} \mathrm{AsS}_{2} \mathrm{Na} \cdot 2 \mathrm{H}_{2} \mathrm{O}$, and Palladium(II) Dimethyldithioarsinate, $\left(\mathrm{Me}_{2} \mathrm{AsS}_{2}\right)_{2} \mathbf{P d}$}

Panayiotis V. Ioannou, ${ }^{*[a]}$ Dimitris G. Vachliotis, ${ }^{[a]}$ Vassilios Nastopoulos, ${ }^{*[a]}$ and Anastasios J. Tasiopoulos ${ }^{[b]}$

${ }^{\text {[a] }}$ Department of Chemistry, University of Patras, Patras, Greece

${ }^{[b]}$ Department of Chemistry, University of Cyprus, Nicosia, Cyprus 1678

Received

Prof. Dr. P. V. Ioannou

Assoc. Prof. Dr. V. Nastopoulos

Department of Chemistry, University of Patras

Patras/Greece

E-mail : $\underline{\text { ioannou@chemistry.upatras.gr }}$

E-mail : nastopoulos@chemistry.upatras.gr 


\begin{abstract}
Palladium(II) acetate in non-deaerated chloroform splits Bunsen's cacodyl disulfide, $\mathrm{Me}_{2} \mathrm{As}(\mathrm{S})-\mathrm{S}-\mathrm{AsMe}_{2}$, giving the slightly-chloroform-soluble complex $\left(\mathrm{Me}_{2} \mathrm{AsS}_{2}\right)_{2} \mathrm{Pd}$ and the arsonium ion $\mathrm{Me}_{2} \mathrm{As}:^{+}$. However, after a few minutes the complex reacted giving $\mathrm{Me}_{2} \mathrm{As}(\mathrm{S})-\mathrm{O}-\mathrm{As}(\mathrm{S}) \mathrm{Me}_{2}$ and other unidentified compound(s). Therefor, the complex $\left(\mathrm{Me}_{2} \mathrm{AsS}_{2}\right)_{2} \mathrm{Pd}$ was prepared from sodium dimethyldithioarsinate dihydrate, $\mathrm{Me}_{2} \mathrm{AsS}_{2} \mathrm{Na} \cdot 2 \mathrm{H}_{2} \mathrm{O}$, and palladium(II) acetate. $\left(\mathrm{Me}_{2} \mathrm{AsS}_{2}\right)_{2} \mathrm{Pd}$ reacts with $\mathrm{Pd}^{\mathrm{II}}$ and $\mathrm{Ph}_{3} \mathrm{P}$ in a different way compared to other $\left(\mathrm{Me}_{2} \mathrm{AsS}_{2}\right)_{\mathrm{X}} \mathrm{M}(\mathrm{M}=$ heavy metal cation $)$ and $\left(\mathrm{Me}_{2} \mathrm{PS}_{2}\right)_{2} \mathrm{Pd}$. The reaction of equimolar quantities of $\mathrm{Me}_{2} \mathrm{AsS}_{2} \mathrm{Na} \cdot 2 \mathrm{H}_{2} \mathrm{O}$ and $\mathrm{Ph}_{3} \mathrm{P}$ under argon involved four consecutive reactions with $\mathrm{Me}_{2} \mathrm{As}-\mathrm{O}-\mathrm{AsMe}_{2}$ and $\mathrm{Me}_{2} \mathrm{AsS}_{2} \mathrm{Na}$ as the final products. The salt $\mathrm{Me}_{2} \mathrm{AsS}_{2} \mathrm{Na} \cdot 2 \mathrm{H}_{2} \mathrm{O}$ has been structurally characterized: triclinic, $P \overline{1}, \mathrm{a}=6.0285(2) \AA \dot{\mathrm{A}}, \mathrm{b}=$ 6.5552(2) Á, $\mathrm{c}=12.1480(4) \AA \hat{\alpha}, \alpha=98.282(2)^{\mathrm{o}}, \beta=93.994(3)^{\mathrm{o}}, \gamma=115.951(3)^{\mathrm{o}}, \mathrm{V}=$ $422.38(3) \AA^{3}, \mathrm{Z}=2, R_{1}=0.0207, w R_{2}=0.0414$.
\end{abstract}

Keywords: Sodium dimethyldithioarsinate; Dimethylarsino dimethylthioarsinate (Bunsen's cacodyl disulfide); Palladium(II) dimethyldithioarsinate; Triphenylphosphine. 


\section{Introduction}

Derivatives of $\mathrm{P}^{\mathrm{V}}$ having the $>\mathrm{P}(\mathrm{S}) \mathrm{S}^{-}$group are of interest both for practical (agricultural and industrial) and theoretical (mode of coordination to metal cations) reasons [1-3].

Derivatives of $\mathrm{As}^{\mathrm{V}}$ such as $(\mathrm{RO})_{2} \mathrm{AsS}_{2}{ }^{-}$and $(\mathrm{RO}) \mathrm{R}^{\prime} \mathrm{AsS}_{2}{ }^{-}$cannot be prepared because of the hydrolytic instability of the RO-As ${ }^{\mathrm{V}}$ bond [4] but those of $\mathrm{Ph}_{2} \mathrm{AsS}_{2}{ }^{-}$and $\mathrm{Me}_{2} \mathrm{AsS}_{2}{ }^{-}$are known. For example, Bunsen [5] prepared salts (complexes) of the unknown [6] $\mathrm{Me}_{2} \mathrm{As}(\mathrm{S}) \mathrm{SH}, \mathrm{LH}, 1$ with $\mathrm{Au}^{\mathrm{I}}, \mathrm{Cu}^{\mathrm{I}}, \mathrm{Pb}^{\mathrm{II}}, \mathrm{Sb}^{\mathrm{III}}$, and $\mathrm{Bi}^{\mathrm{III}}$ by reacting the so-called Bunsen's cacodyl disulfide, $\mathrm{Me}_{2} \mathrm{As}(\mathrm{S})-\mathrm{S}-\mathrm{AsMe}_{2} 2$ with metal salts according to the simplified equations (1) and (2). The complexes $\mathrm{L}_{2} \mathrm{Hg}$ and LAg have also been prepared using the reaction of equation (1) and possible mechanisms for the reactions of equations (1) and (2) have been proposed [7].

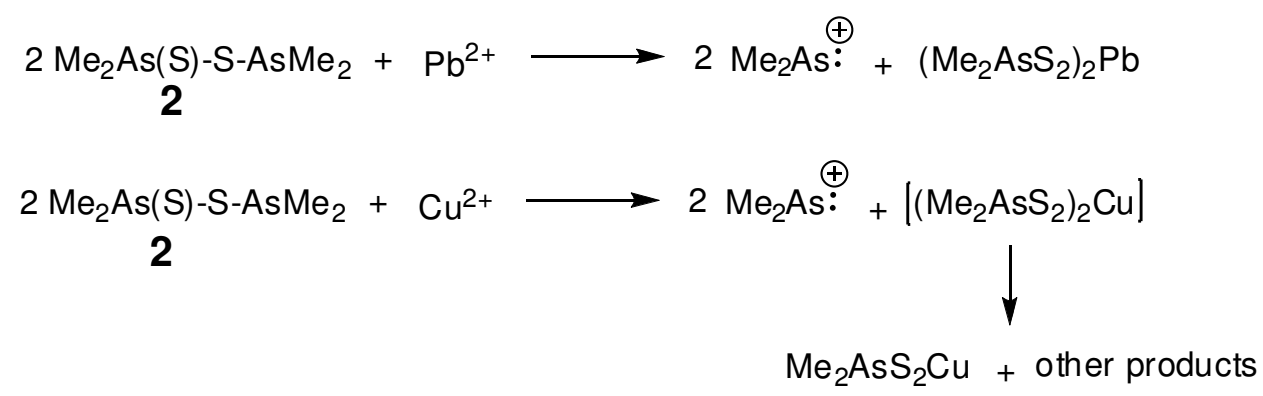

Casey et al. [8] prepared the $\mathrm{L}_{\mathrm{x}} \mathrm{M}$ complexes with $\mathrm{M}=\mathrm{Cr}^{\mathrm{III}}, \mathrm{Mn}^{\mathrm{II}}, \mathrm{Co}^{\mathrm{II}}, \mathrm{Ni}^{\mathrm{II}}, \mathrm{Cu}^{\mathrm{I}}, \mathrm{Zn}^{\mathrm{II}}, \mathrm{Cd}^{\mathrm{II}}$, and In ${ }^{\mathrm{III}}$ according to equations (3) and (4) . 


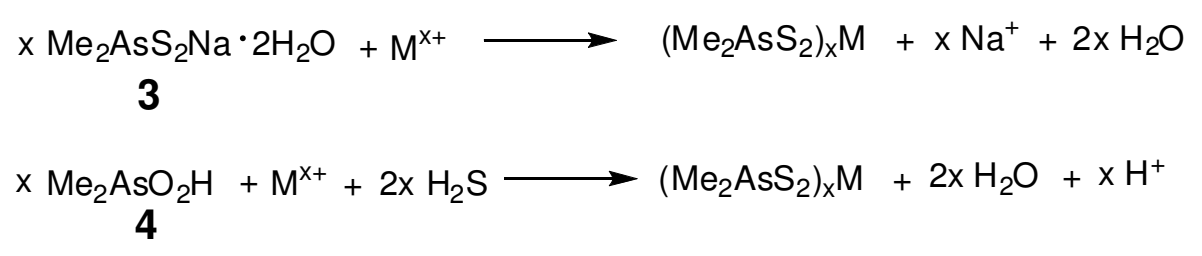

At the same time Förster et al. [9] prepared the $\mathrm{L}_{\mathrm{x}} \mathrm{M}$ complexes with $\mathrm{M}=\mathrm{Cr}^{\mathrm{III}}, \mathrm{Co}^{\mathrm{II}}, \mathrm{Ni}^{\mathrm{II}}, \mathrm{Zn}^{\mathrm{II}}$, and $\mathrm{Cd}^{\mathrm{II}}$, while the $\mathrm{Sn}^{\mathrm{IV}}$ was prepared later on [10], both using the reaction of equation (3).

The $\mathrm{Me}_{2} \mathrm{AsS}_{2}^{-}, \mathrm{L}^{-}$, anion is a ligand for organometallic derivatives of $\mathrm{Sn}^{\text {IV }}$ [10], $\mathrm{Sb}^{\mathrm{III}}$ [11], $\mathrm{Si}^{\mathrm{IV}}, \mathrm{Ge}^{\mathrm{IV}}$ and $\mathrm{Pb}^{\mathrm{IV}}$ [12], $\mathrm{Pt}^{\mathrm{IV}}$ [13], and $\mathrm{V}^{\mathrm{IV}}$ [14] as well as for the carbonyls of $\mathrm{Mn}^{\mathrm{I}}$ and $\operatorname{Re}^{\mathrm{I}}[15]$.

The crystal structures of $\mathrm{LK} \cdot 2 \mathrm{H}_{2} \mathrm{O}$ [16], $\mathrm{L}_{3} \mathrm{Bi}$ [17], $\mathrm{L}_{3} \mathrm{In}$ [18], $\mathrm{L}_{3} \mathrm{Cr}$ [19], $\mathrm{Ph}_{2} \mathrm{SbL}$ [20] and $\mathrm{Me}_{2} \mathrm{SnL}_{2}$ [21] have been reported as well as the solid state IR spectra [8] and magnetic properties [9] of some complexes. The thermal behaviour of the complexes prepared by Bunsen was studied by him in addition to a few chemical properties [5], and we have studied the same as well [7].

The key salt, $\mathrm{Me}_{2} \mathrm{As}(\mathrm{S}) \mathrm{S}^{-} \mathrm{Na}^{+} \cdot 2 \mathrm{H}_{2} \mathrm{O}$ 3, has been prepared according to equations (5) [8] and (6) [9].

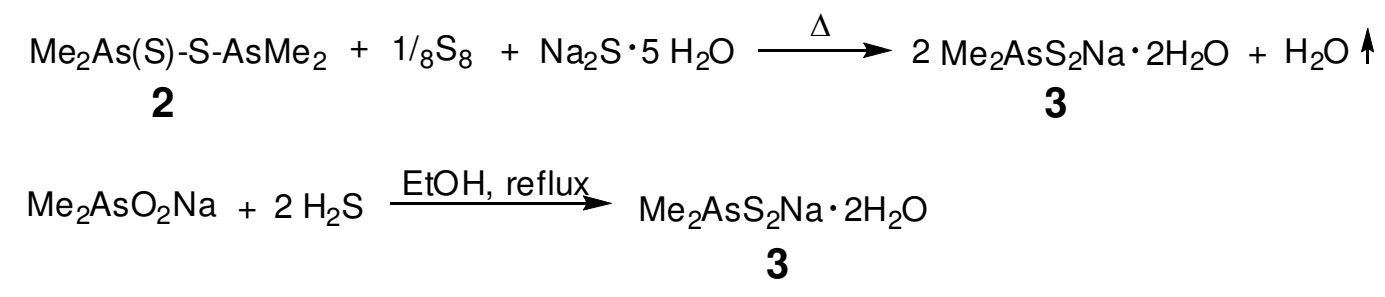

We prepared Bunsen's cacodyl disulfide $2[5,22]$ and studied its electrophilic character towards Lewis bases of group 15 [6] and nucleophilic character towards Lewis acids: heavy metal cations [7] and molecular halides and thallium(III) acetate of group 13 
[23]. Heavy metal salts, split 2 into two parts, equations (1) and (2), i.e. to the complexes $L_{x} M$ and to arsenium ion $\mathrm{Me}_{2} \mathrm{As}:^{+}[7,23]$.

Since arsenium ions are reactive species, we wanted to find a salt of $\mathrm{M}^{\mathrm{x}+}$ soluble in non-polar solvents in order to react with $\mathbf{2}$ to give, preferably, an insoluble $\mathrm{L}_{\mathrm{x}} \mathrm{M}$ and a soluble $\mathrm{Me}_{2} \mathrm{As}^{{ }^{+}}$. This strategy would allow us to study the properties of $\mathrm{Me}_{2} \mathrm{As}:^{+}$in greater detail than previously done [7]. Palladium acetate is soluble in chloroform, has a diamagnetic $\mathrm{Pd}^{\mathrm{II}}$, its reaction with 2 can be studied by ${ }^{1} \mathrm{H}$ NMR, and we expected $\mathrm{L}_{2} \mathrm{Pd}$ to be insoluble in chloroform as were the other $\mathrm{L}_{\mathrm{x}} \mathrm{M}$ complexes prepared so far.

In this paper we present our results on the reaction of palladium(II) acetate with $\mathbf{2}$ which proved to be complicated and did not afford $\left(\mathrm{Me}_{2} \mathrm{AsS}_{2}\right)_{2} \mathrm{Pd} \mathbf{5}$. The complex $\mathbf{5}$ was, however, prepared from $\mathbf{3}$, equation (3). Because 3 prepared according to equation (5) had a melting point $222-224{ }^{\circ} \mathrm{C}$ (this work) while when prepared according to equation (6) had a melting point $181-182^{\circ} \mathrm{C}$ [9] and $>200{ }^{\circ} \mathrm{C}$ [24], we determined its structure by X-ray analysis.

\section{Results and discussion}


Table 1. ${ }^{1} \mathrm{H}$ NMR values of methyl and phenyl groups in $\mathrm{CDCl}_{3}$ and $\mathrm{CD}_{3} \mathrm{OD}$, and ${ }^{31} \mathrm{P} \mathrm{NMR}$ values of phosphorus compounds encountered in this work. Our $\delta$ values for the methyl protons have a range of less than $\pm 0.002 \mathrm{ppm}$ of the quoted values $(\mathrm{s}=$ singlet, $\mathrm{m}=$ multiplet $)$.

13

$\mathrm{CDCl}_{3}$

$\mathrm{CD}_{3} \mathrm{OD}$

Compound

\begin{tabular}{|l|l|}
$\mathrm{Pd}(\mathrm{OAc})_{2}$ & $1.997 \mathrm{~s}$
\end{tabular}

\begin{tabular}{|l|l|l}
$\mathrm{AcOH}$ & $2.069 \mathrm{~s}$ & (4)
\end{tabular}

$\mathrm{Me}_{2} \mathrm{As}(\mathrm{S})-\mathrm{S}-\mathrm{AsMe}_{2}$

$2.164 \mathrm{~s}, 1.544 \mathrm{~s}[6]$

\begin{tabular}{l|l|l}
\hline $\mathbf{5})^{\mathrm{a}}$ & $\left(\mathrm{Me}_{2} \mathrm{AsS}_{2}\right)_{2} \mathrm{Pd}$ & 2.21 \\
\hline$(6)$ & $\mathrm{Me}_{2} \mathrm{As}-\mathrm{S}-\mathrm{AsMe}$ & 1.39 \\
\hline
\end{tabular}

$\mathrm{Me}_{2}$

$2.212 \mathrm{~s}$

$(8)$

\begin{tabular}{l|l|l}
$\mathrm{Me}_{2} \mathrm{As}-\mathrm{S}^{-}$ & 1.98(
\end{tabular}

$1.399 \mathrm{~s}[6]$

$1.980 \rightarrow 1.891 \mathrm{~s}[6]$

$\left(\mathbf{7} \cdot \mathrm{Na}^{+}\right)$

Compound

(8)

(9)

$1.1[35]$

(15)

$\mathrm{Me}_{2} \mathrm{As}-\mathrm{AsMe}_{2}$

$\mathrm{Me}_{2} \mathrm{As}-\mathrm{SS}-\mathrm{AsMe}_{2}$

$\mathrm{Me}_{2} \mathrm{As}(\mathrm{S})-\mathrm{O}-\mathrm{As}(\mathrm{S}) \mathrm{Me}_{2}$

$\mathrm{Ph}_{3} \mathrm{P}$

\begin{tabular}{l|l}
$\mathrm{Ph}_{3} \mathrm{P}$ & $7.30 \mathrm{~s}$ \\
\hline
\end{tabular}

\begin{tabular}{|l|l|}
\hline $\mathrm{Ph}_{3} \mathrm{P}=\mathrm{O}$ & $7.47 \mathrm{~m}, 7.55 \mathrm{~m}, 7.68 \mathrm{~m}$ \\
\hline $\mathrm{Ph}_{3} \mathrm{P}=\mathrm{S}$ & $7.44 \mathrm{~m}, 7.50 \mathrm{~m}, 7.72 \mathrm{~m} \mathrm{[6]}$ \\
\hline
\end{tabular}

a: $2.250 \mathrm{~s}$ in $\left[\mathrm{D}_{6}\right] \mathrm{DMSO}$

b: $1.993 \mathrm{~s}, 1.95$ [22], 1.99 [24] in $\mathrm{D}_{2} \mathrm{O}$

c: $0.1 \mathrm{M}$

d: mixture, both $0.1 \mathrm{M}$

\begin{abstract}
To simplify the text, in Table 1 we summarize the ${ }^{1} \mathrm{H}$ and ${ }^{31} \mathrm{P}$ NMR chemical shifts, in various solvents, of the compounds encountered in this work.
\end{abstract}

\title{
Preparation and physical properties of $\mathrm{Me}_{2} \mathrm{AsS} \mathrm{S}_{2} \mathrm{Na} \cdot 2 \mathrm{H}_{2} \mathrm{O}$ (3) and $\left(\mathrm{Me}_{2} \mathrm{AsS} \mathrm{S}_{2}\right)_{2} \mathrm{Pd}(5)$
}


Casey et al. [8] prepared the salt 3, equation (5), using the dihydrate, $\mathrm{Na}_{2} \mathrm{~S} \cdot 2 \mathrm{H}_{2} \mathrm{O}$, a rare compound [26] (but see ref. [27]). For the same reaction we used the pentahydrate, $\mathrm{Na}_{2} \mathrm{~S} \cdot 5 \mathrm{H}_{2} \mathrm{O}$ [28, 29]. The nonahydrate, $\mathrm{Na}_{2} \mathrm{~S} \cdot 9 \mathrm{H}_{2} \mathrm{O}$, does not allow a satisfactory homogenization of the solid reactants because it melted [27] during the grinding. The smaller the scale (e.g. $0.5 \mathrm{mmol})$ the better the yields $(\sim 95 \%)$ because of the better heating of the solid mixture. The preparation of $\mathbf{3}$ from $\mathbf{2}$ according to equation (5) evidently involves the ring opening of $S_{8}$ by $S^{2-}$ [30] to give ${ }^{-} S_{-} S_{7-} S^{-}$. Then, this nucleophile reacts with 2 , most likely at the As=S sulfur [6], giving, after successive cycles, the salt 3 .

The complex $\mathbf{5}$ was prepared from $\mathbf{3}$ by a stepwise replacement of the acetate groups of the trimeric $[31,32]$ palladium(II) acetate, $\left[\mathrm{Pd}(\mathrm{OAc})_{2}\right]_{3}$, under conditions [7] which prevented the interaction of $\mathrm{Pd}^{\mathrm{II}}$ with the formed 5. The complex $\mathbf{5}$ keeps tenaciously $\mathrm{MeOH}$, AcOH and probably $\mathrm{H}_{2} \mathrm{O}$ (by IR and ${ }^{1} \mathrm{H}$ NMR) and prolonged drying over concentrated sulfuric acid [5, 7] was necessary for satisfactory elemental analyses. While $\mathbf{3}$ melted, $\mathbf{5}$ upon heating decomposed at $\sim 195{ }^{\circ} \mathrm{C}$ to $\mathrm{PdS}$ and the foul-smelling $\mathrm{Me}_{2} \mathrm{As}-\mathrm{S}-\mathrm{AsMe}_{2} 6$ indicating that the formation of heavy metal sulfides, $\mathrm{M}_{2} \mathrm{~S}_{\mathrm{x}}$, is the driving force for such a decomposition $[5,7,23]$. The poor solubility of 5 points towards a polymeric structure. A saturated solution of 5 in $\mathrm{CDCl}_{3}$ resonated at $2.212 \mathrm{ppm}$, Table 1, quite close (2.246 ppm) to the chloroformsoluble $\mathrm{Me}_{2} \mathrm{AsS}_{2}{ }^{-} \mathrm{Me}_{2} \mathrm{AsS}_{-\mathrm{NEt}_{3}}{ }^{+}$[6]. Its IR (KBr) spectrum showed the bands found [7, 8] and assigned [8] in other $\left(\mathrm{Me}_{2} \mathrm{AsS}_{2}\right)_{\mathrm{X}} \mathrm{M}$ complexes.

\section{Chemical properties of $\mathrm{Me}_{2} \mathrm{As} \mathrm{S}_{2} \mathrm{Na} \cdot 2 \mathrm{H}_{2} \mathrm{O}$ (3) and $\left(\mathrm{Me}_{2} \mathrm{As} \mathrm{S}_{2}\right)_{2} \mathrm{Pd}(5)$}

Attempted desulfurization of $\left(\mathrm{Me}_{2} \mathrm{AsS}_{2}\right)_{\mathrm{x}} \mathrm{M}(\mathrm{M}=$ heavy metal cation $)$ by $\mathrm{Ph}_{3} \mathrm{P}$ [or $\left.(\mathrm{MeO})_{3} \mathrm{P}\right]$ did not give the salts $\left(\mathrm{Me}_{2} \mathrm{AsS}\right)_{\mathrm{x}} \mathrm{M}$ with the desired [33] thiolato ligand $\mathrm{Me}_{2} \mathrm{As}-\mathrm{S}^{-} 7$ but $\mathrm{Ph}_{3} \mathrm{P}=\mathrm{S}$ [or $(\mathrm{MeO})_{3} \mathrm{P}=\mathrm{S}$ ] together with the metal sufide $\mathrm{M}_{2} \mathrm{~S}_{\mathrm{x}}$ and $\mathrm{Me}_{2} \mathrm{As}-\mathrm{S}-\mathrm{AsMe}_{2} \mathbf{6}$ due to 
the affinity of these cations to sulfur [7]. Since $\mathrm{Na}^{+}$does not have such an affinity, we tried to desulfurize 3 with $\mathrm{Ph}_{3} \mathrm{P}$ hoping to get $\mathrm{Me}_{2} \mathrm{AsSS}^{-} \mathrm{Na}^{+}, 7 \cdot \mathrm{Na}^{+}$. However, the course of the desulfurization was unexpected because 4 consecutive reactions took place.

Upon dissolution of an equimolar quantity of $\mathrm{Ph}_{3} \mathrm{P}$ and $\mathbf{3}$ in $\mathrm{CD}_{3} \mathrm{OD}$ under argon the ${ }^{1} \mathrm{H}$ NMR showed practically no binding of $\mathrm{Ph}_{3} \mathrm{P}$ to 3 . In $1 \mathrm{~h} \mathrm{Ph}_{3} \mathrm{P}=\mathrm{S}$ started precipitating and the ${ }^{1} \mathrm{H}$ NMR spectrum of the supernatant showed the presence of $\mathbf{3}$ that had not yet reacted and a singlet due to $7 \cdot \mathrm{Na}^{+}$. In $20 \mathrm{~h}$ the supernatant contained $\mathbf{3}, \mathrm{Me}_{2} \mathrm{As}-\mathrm{AsMe} \mathrm{Me}_{2} \mathbf{8}, \mathrm{Me}_{2} \mathrm{As}(\mathrm{S}) \mathrm{O}^{-}$ $\mathrm{Na}^{+}$9, and $\mathrm{Me}_{2} \mathrm{As}(\mathrm{O}) \mathrm{O}^{-} \mathrm{Na}^{+} \mathbf{1 0}$ with a mole ratio of 1.00:1.60:0.04:0.03. The singlet at 1.736 was attributed to $\mathrm{Me}_{2} \mathrm{As}(\mathrm{S}) \mathrm{O}^{-} \mathrm{Na}^{+} 9$ because the free acid $\mathrm{Me}_{2} \mathrm{As}(\mathrm{S}) \mathrm{OH}$ in $\mathrm{CD}_{3} \mathrm{OD} / \mathrm{D}_{2} \mathrm{O}$ 3:1 resonated at $2.056 \mathrm{ppm}$ [6]. Triphenylphosphine was totally consumed in $48 \mathrm{~h}$ by which time the ${ }^{31} \mathrm{P}$ NMR spectrum showed $\mathrm{Ph}_{3} \mathrm{P}=\mathrm{S}$ and very little $\mathrm{Ph}_{3} \mathrm{P}=\mathrm{O}$, while the ${ }^{1} \mathrm{H}$ NMR spectrum showed 3, $\mathrm{Me}_{2} \mathrm{As}-\mathrm{O}-\mathrm{AsMe}_{2} \mathbf{1 1}, \mathbf{9}$, and 10 with a mole ratio of 1.00:1.20:0.06:0.04. After 5 days the ratio remained unchanged while a disagreeable odor, due to $\mathbf{1 1}$, developed resembling that of $6[7]$.

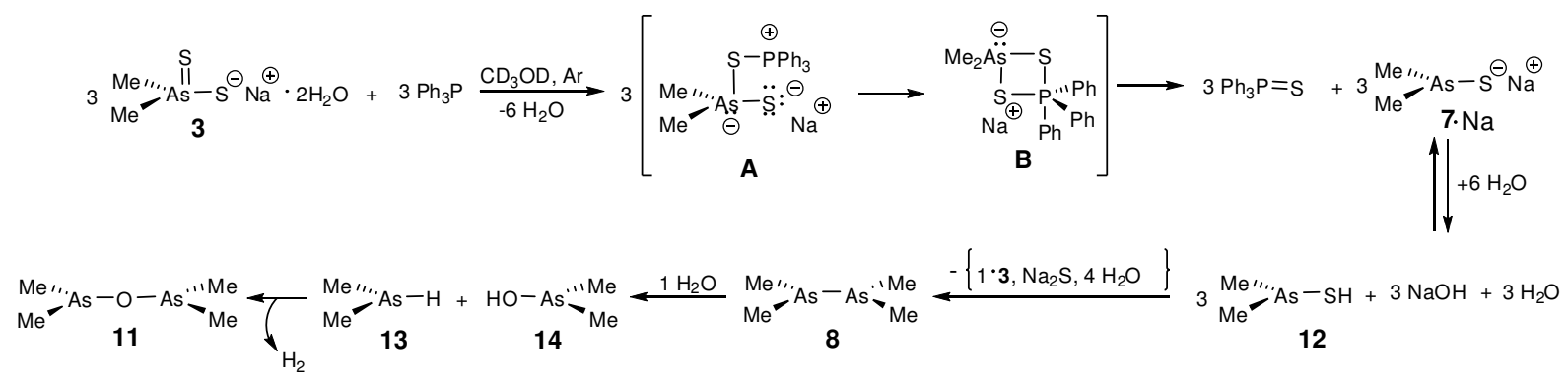

Scheme 1

These observations can be rationalized as in Scheme 1. Binding of $\mathrm{Ph}_{3} \mathrm{P}$ to $\mathbf{3}$ was absent or very weak because the intermediate $\mathbf{A}$ has vicinal negatively charged atoms. However, the production of $\mathrm{Ph}_{3} \mathrm{P}=\mathrm{S}$ must arise from the pentacoordinated intermediate $\mathbf{B}$, and the production of $\mathrm{Ph}_{3} \mathrm{P}=\mathrm{O}$ is discussed below. The product first formed must be $\mathbf{7} \cdot \mathrm{Na}^{+}$which 
will be in equilibrium with the unstable (but see [34]) thioarsinous acid 12. This acid suffers disproportionation as Tani et al. [33] suggested giving 3, 8, and $\mathrm{Na}_{2} \mathrm{~S}$. The highly reactive diarsine 8 resonated at $\sim 1.25 \mathrm{ppm}\left(1.1 \mathrm{ppm}\right.$ in $\mathrm{CDCl}_{3}$ [35]) and by reaction with $\mathrm{H}_{2} \mathrm{O}$ should give 13 and 14 [36]. The dimethylarsine, being a strong reducing agent [37], must react with the dimethylarsinous acid $\mathbf{1 4}$ to give the anhydride $\mathbf{1 1}$ and dihydrogen.

Admitting dioxygen to the solution, expelled some $\mathbf{1 1}$ and the rest was slowly oxidized in the presence of the waters of $\mathbf{3}$ to cacodylic acid $\mathbf{4}$ which, in the presence of the hydrolysable $\mathrm{Na}_{2} \mathrm{~S}$, gave the salt $\mathbf{1 0}$. The production of the salt $\mathbf{9}$ is more difficult to explain: it probably arises from the oxidation of $S^{2-}$ to " $S$ " which is then captured by an As" atom.

Running the desulfurization of $\mathbf{3}$ by $\mathrm{Ph}_{3} \mathrm{P}$ in air we found the same final arseniccontaining compounds but, now, the production of $\mathrm{Ph}_{3} \mathrm{P}=\mathrm{O}$ was significant due to the reaction of $\mathbf{8}$ with dioxygen which should give [38] $\mathrm{Me}_{2} \mathrm{As}-\mathrm{OO}-\mathrm{AsMe}_{2}$ which, in turn, will be deoxygenated by $\mathrm{Ph}_{3} \mathrm{P}$.

These attempts at the preparation of the $\mathrm{Me}_{2} \mathrm{As}-\mathrm{S}^{-}$anion $\mathbf{7}$ as well as those tried earlier [7], show that 7 can be produced but it seems that it is not stable.

A suspension of 5 in $\mathrm{CDCl}_{3}$ reacted with $\mathrm{Ph}_{3} \mathrm{P}$ (1:2 mole ratio) giving, by ${ }^{1} \mathrm{H} \mathrm{NMR}$, $\mathrm{Ph}_{3} \mathrm{P}=\mathrm{S}$ and a prominent singlet attributable to unstable [22, 23] $\mathrm{Me}_{2} \mathrm{As}-\mathrm{SS}-\mathrm{AsMe}_{2} \mathbf{1 5}$ and not to the putrid 6 [6], which diminished with time giving a complex ${ }^{1} \mathrm{H}$ NMR spectrum in the region of 1.26-2.00 ppm. $\mathrm{PdS}$ was not produced. Thus, the reaction of 5 with $\mathrm{Ph}_{3} \mathrm{P}$ is not in line with the other similar reactions of $\left(\mathrm{Me}_{2} \mathrm{AsS}_{2}\right)_{\mathrm{x}} \mathrm{M}$ [7] and is not amenable to a simple interpretation. The behaviour of 5 also contrasts the behaviour of $\left(\mathrm{Me}_{2} \mathrm{PS}_{2}\right)_{2} \mathrm{Pd}$ with phosphines, e.g. $\left(\mathrm{Me}_{2} \mathrm{PS}_{2}\right)_{2} \mathrm{Pd}$ adds one and two $\mathrm{Ph}_{3} \mathrm{P}$ ligands to give new complexes [39, 40].

The complex $\mathbf{5}$ dissolved, at RT, in pyridine was recovered intact by precipitation with $\mathrm{Et}_{2} \mathrm{O}$ indicating that pyridine does not coordinate to the complexed $\mathrm{Pd}^{\mathrm{II}}$. When the pyridine 
solution was heated at $80{ }^{\circ} \mathrm{C}$ for $3 \mathrm{~h}$, and cooled at $-20{ }^{\circ} \mathrm{C}[31]$, a very small amount of a brown-black solid was formed. The reaction was not studied further.

While heavy metal complexes, e.g. $\left(\mathrm{Me}_{2} \mathrm{AsS}_{2}\right)_{2} \mathrm{~Pb}$, react in non-deaerated methanol with their own cations, e.g. $\mathrm{Pb}^{\mathrm{II}}$, to give $\mathrm{PbS}$ and a solution of cacodylic acid $\mathbf{4}$ plus $\mathrm{Me}_{2} \mathrm{As}(\mathrm{S})-\mathrm{O}-\mathrm{As}(\mathrm{S}) \mathrm{Me}_{2} \mathbf{1 6}$ [7], the reaction of 5 with $\mathrm{Pd}(\mathrm{OAc})_{2}$ (1:1 mole ratio) in nondeaerated chloroform gave an amorphous black solid and a solution containing only acetic acid implying that all added $\mathrm{Pd}^{\mathrm{II}}$ and all $\mathrm{Me}_{2} \mathrm{As}$ - groups have been incorporated in the solid. With twice the amount of $\operatorname{Pd}(\mathrm{OAc})_{2}$ over 5, the black solid was formed and the orange supernatant contained $\mathrm{AcOH}$ and the excess of $\mathrm{Pd}(\mathrm{OAc})_{2}$. Finally, the black solid was formed when a chloroform solution of $\mathrm{Pd}(\mathrm{OAc})_{2}$ was added to an equimolar quantity of $\mathbf{3}$ in methanol where the formed 5 reacted with the excess $\mathrm{Pd}^{\mathrm{II}}$. The identity of the, insoluble in all common solvents, black precipitates could not be established from the elemental analyses and the weights. Being amorphous, the quality of the powder X-ray diffraction spectrum was poor. Its IR $(\mathrm{KBr})$ spectrum was similar to that of $\mathbf{5}$, but its bands were somewhat broader and the intensity of the As-S stretching of the $\mathrm{AsS}_{2} \mathrm{Pd}$ ring at $454 \mathrm{~cm}^{-1}$ [8] was much weaker than that of 5 .

\section{The reaction of Bunsen's cacodyl disulfide (2) with $\mathrm{Pd}(\mathrm{OAc})_{2}$}

In all, so far studied, reactions of 2 with heavy metal cations [equations (1) and (2)] the chloroform-soluble $\mathrm{Me}_{2} \mathrm{As}:^{+}$did not react with the insoluble $\mathrm{L}_{\mathrm{x}} \mathrm{M}$ complexes but it gave cacodylic acid 4 [7]. The reaction of 2 with $\mathrm{Pd}(\mathrm{OAc})_{2}$ under a 1:1 stoichiometry in $\mathrm{CDCl}_{3}$ gave the black solid described in the previous subsection, indicating that $\mathbf{2}$ does produce $\mathbf{5}$ which then reacts with the excess of $\mathrm{Pd}(\mathrm{OAc})_{2}$. However, the dark red supernatant contained, by ${ }^{1} \mathrm{H}$ NMR, apart from $\mathrm{AcOH}$, two other prominent singlets at 1.434 and $2.180 \mathrm{ppm}$ 
belonging to unknown compound(s) probably arising from the reaction of $\mathrm{Me}_{2} \mathrm{As}:^{+}$with $\mathbf{5}$ and with 2. The singlets are not due to $\mathrm{CH}_{3} \mathrm{COO}-\mathrm{AsMe} \mathrm{e}_{2}$ because, in $\mathrm{CDCl}_{3}$, its methyl groups resonate at 2.47 and $1.84 \mathrm{ppm}$ [41]. It seems, therefore, that when $\mathrm{Pd}^{\mathrm{II}}$ is in excess, $\mathrm{Pd}^{\mathrm{II}}$, in preference to $\mathrm{Me}_{2} \mathrm{As}:^{+}$, acts on the formed $\mathbf{5}$ giving the black solid. With stoichiometric amounts of the reactants, equation (1), a small amount (visually) of $\mathbf{5}$ was initially formed and then reacted giving a clear solution (without the black solid) containing by ${ }^{1} \mathrm{H}$ NMR: free $\mathrm{AcOH}$ plus another unknown compound (both resonating at $2.082 \mathrm{ppm}), \mathrm{Me}_{2} \mathrm{As}(\mathrm{S})-\mathrm{O}-$ $\mathrm{As}(\mathrm{S}) \mathrm{Me}_{2} 16$ [7], and smaller amounts of 2, 5, and 15. The latter was produced at the early stages and remained unchanged. Thus, when there is no $\mathrm{Pd}^{\mathrm{II}}$ in the system, then $\mathrm{Me}_{2} \mathrm{As}^{+}$ attacks on the insoluble $\mathrm{L}_{2} \mathrm{Pd} \mathbf{5}$, most likely on $\mathrm{As}=\mathrm{S}$ sulfur, leading to the production of $\mathbf{1 5}$ which is unstable when not complexed [22, 23]. The oxidation of $\mathbf{1 5}$ to the main product $\mathbf{1 6}$ probably involves activated dioxygen [7] and an activator can be $\mathrm{Pd}^{\mathrm{II}}$ for it is known that $\mathrm{Pd}^{\mathrm{II}}$ can catalyse the air oxidation of secondary alcohols to ketones [42, 43]. Finally, under a 3:1 stoichiometry, the dark red-brown solution had very little $\mathbf{2}$ (although it was in excess) and the stronger singlets were due to 16, implying a catalytic conversion of $\mathbf{2}$ to $\mathbf{1 6}$, and free $\mathrm{AcOH}$ plus the unknown compound (resonating at $2.082 \mathrm{ppm}$ ). In the last two cases it is not known how $\mathrm{Pd}^{\mathrm{II}}$ is kept in solution.

Summarizing, in Bunsen's cacodyl disulfide $\mathrm{Me}_{2} \mathrm{As}(\mathrm{S})-\mathrm{S}-\mathrm{AsMe}_{2} 2$ and in the complexes $\left(\mathrm{Me}_{2} \mathrm{AsS}_{2}\right)_{\mathrm{x}} \mathrm{M}$, the $\mathrm{As}=\mathrm{S}$ sulfur is the atom on which nucleophiles and electrophiles attack. But the behaviour of the palladium(II) complex 5 towards nucleophiles and electrophiles is exceptional compared to the other $\mathrm{L}_{\mathrm{x}} \mathrm{M}$ studied so far and this can be due to it being a planar $\mathrm{d}^{8}$ complex.

The crystal structure of $\mathrm{Me}_{2} \mathrm{As} \mathrm{S}_{2} \mathrm{Na} \cdot 2 \mathrm{H}_{2} \mathrm{O}$ (3) 
Table 2. Crystal data and structure refinement for $\mathrm{Me}_{2} \mathrm{AsS}_{2} \mathrm{Na} \cdot 2 \mathrm{H}_{2} \mathrm{O}(3)$

\begin{tabular}{ll}
\hline Formula & $\mathrm{C}_{2} \mathrm{H}_{10} \mathrm{AsNaO}_{2} \mathrm{~S}_{2}$ \\
Molecular weight $/ \mathrm{g} \mathrm{mol}^{-1}$ & 228.13 \\
Crystal system & Triclinic \\
Space group & $P \overline{1}$ \\
Unit cell dimensions & \\
$a / \AA$ & $6.0285(2)$ \\
$b / \AA$ & $6.5552(2)$ \\
$c / \AA$ & $12.1480(4)$ \\
$\alpha /$ deg & $98.282(2)$ \\
$\beta /$ deg & $93.994(3)$ \\
$\gamma /$ deg & $115.951(3)$ \\
Volume $/ \AA^{3}$ & $422.38(3)$ \\
$Z, D_{\text {calc }} /($ Mg/m & \\
Absorption coefficient $/ \mathrm{mm}^{-1}$ & $2,1.794$ \\
$F(000)$ & 4.496 \\
Crystal size /mm & 228 \\
$\theta$ range for data collection /deg & $0.14 \times 0.11 \times 0.08$ \\
Reflections collected / unique & 3.43 to 28.50 \\
Index ranges & $7358 / 2117\left(R_{\text {int }}=0.0295\right)$ \\
Refinement method & $-8 \leq h \leq 8,-8 \leq k \leq 8,-15 \leq l \leq 16$ \\
Data/ restraints /parameters & Full-matrix least-squares on $F^{2}$ \\
Goodness-of-fit on $F^{2}$ & $2117 / 4 / 87$ \\
$R_{1}, w R_{2}$ indices $[I>2 \sigma(I)]$ & 0.983 \\
$R_{1}, w R_{2}$ indices $($ all data) & $0.0207,0.0414$ \\
Largest diff. peak and hole /e $\AA^{-3}$ & $0.0275,0.0422$ \\
\hline & 0.653 and -0.328 \\
\hline
\end{tabular}


Table 3. Atomic coordinates ${ }^{a)}$ and thermal displacement parameters ${ }^{\mathrm{b})}$ for $\mathrm{Me}_{2} \mathrm{AsS}_{2} \mathrm{Na} \cdot 2 \mathrm{H}_{2} \mathrm{O}$.

\begin{tabular}{lllll}
\hline Atom & $x$ & $y$ & $z$ & $U_{\text {eq }}\left(\AA^{2}\right)$ \\
\hline As & $0.10406(3)$ & $0.43900(3)$ & $0.701426(15)$ & $0.00969(6)$ \\
C1 & $0.3310(4)$ & $0.3832(4)$ & $0.61353(16)$ & $0.0160(4)$ \\
C2 & $-0.2073(4)$ & $0.1660(3)$ & $0.65079(17)$ & $0.0164(4)$ \\
S1 & $0.22176(9)$ & $0.46255(8)$ & $0.87539(4)$ & $0.01113(10)$ \\
S2 & $0.07530(9)$ & $0.73526(8)$ & $0.66564(4)$ & $0.01332(11)$ \\
Na & $-0.17689(13)$ & $0.15187(13)$ & $0.98329(6)$ & $0.01291(17)$ \\
O1 & $-0.5651(2)$ & $0.0840(2)$ & $0.89047(11)$ & $0.0138(3)$ \\
H11 & $-0.626(4)$ & $0.176(3)$ & $0.8844(18)$ & 0.021 \\
H12 & $-0.644(4)$ & $-0.007(3)$ & $0.8287(14)$ & 0.021 \\
O2 & $-0.1765(2)$ & $-0.1912(2)$ & $0.88900(11)$ & $0.0144(3)$ \\
H21 & $-0.324(3)$ & $-0.292(3)$ & $0.8847(19)$ & 0.022 \\
H22 & $-0.128(4)$ & $-0.208(4)$ & $0.8260(13)$ & 0.022 \\
& & & & \\
\hline
\end{tabular}

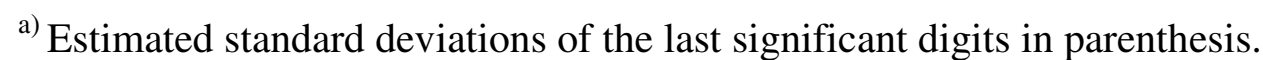

${ }^{\text {b) }} U_{\text {eq }}$ is defined as one third of the trace of the orthogonalized $U_{\text {ij }}$ tensor.

Table 4. Selected structural data for $\mathrm{Me}_{2} \mathrm{AsS}_{2} \mathrm{Na} \cdot 2 \mathrm{H}_{2} \mathrm{O}$.

Bond lengths $(\AA)$ and bond angles $\left(^{\circ}\right)$

\begin{tabular}{|c|c|c|c|c|}
\hline As-C1 & $1.9169(18)$ & \multicolumn{2}{|c|}{$\mathrm{Na}-\mathrm{O} 1$} & $2.3503(14)$ \\
\hline As-C2 & $1.920(2)$ & \multicolumn{2}{|c|}{$\mathrm{Na}-\mathrm{O} 2$} & $2.3732(15)$ \\
\hline As-S1 & $2.1435(5)$ & \multicolumn{2}{|c|}{$\mathrm{Na}-\mathrm{O} 1^{\mathrm{iii}}$} & $2.4641(16)$ \\
\hline As-S2 & $2.1255(5)$ & \multicolumn{2}{|c|}{$\mathrm{Na}-\mathrm{O} 2^{\mathrm{ii}}$} & $2.4403(15)$ \\
\hline $\mathrm{S} 1-\mathrm{Na}$ & $2.9267(9)$ & \multicolumn{2}{|c|}{$\mathrm{Na}-\mathrm{Na}^{\mathrm{i}}$} & $4.0461(15)$ \\
\hline $\mathrm{S} 1-\mathrm{Na}^{\mathrm{i}}$ & $2.9701(8)$ & \multicolumn{2}{|c|}{$\mathrm{Na}-\mathrm{Na}^{\mathrm{ii}}$} & $3.5364(13)$ \\
\hline & & \multicolumn{2}{|c|}{$\mathrm{Na}-\mathrm{Na}{ }^{\mathrm{iii}}$} & $3.6014(15)$ \\
\hline $\mathrm{C} 1-\mathrm{As}-\mathrm{C} 2$ & $103.74(9)$ & \multicolumn{2}{|c|}{$\mathrm{As}-\mathrm{S} 1-\mathrm{Na}$} & $112.74(2)$ \\
\hline $\mathrm{C} 1-\mathrm{As}-\mathrm{S} 2$ & $109.64(6)$ & \multicolumn{2}{|c|}{ As- $-\mathrm{S} 1-\mathrm{Na}^{\mathrm{i}}$} & $110.28(2)$ \\
\hline $\mathrm{C} 2-\mathrm{As}-\mathrm{S} 2$ & $110.48(6)$ & \multicolumn{2}{|c|}{$\mathrm{Na}-\mathrm{S} 1-\mathrm{Na}^{\mathrm{i}}$} & $86.65(2)$ \\
\hline $\mathrm{C} 1-\mathrm{As}-\mathrm{S} 1$ & $108.96(6)$ & \multicolumn{2}{|c|}{$\mathrm{S} 1-\mathrm{Na}-\mathrm{O} 1^{\mathrm{iii}}$} & $166.93(4)$ \\
\hline $\mathrm{C} 2-\mathrm{As}-\mathrm{S} 1$ & $109.30(6)$ & \multicolumn{2}{|c|}{$\mathrm{O} 2-\mathrm{Na}-\mathrm{S} 1^{\mathrm{i}}$} & $171.35(5)$ \\
\hline $\mathrm{S} 1-\mathrm{As}-\mathrm{S} 2$ & $114.201(19)$ & \multicolumn{2}{|c|}{$\mathrm{O} 1-\mathrm{Na}-\mathrm{O} 2^{\mathrm{ii}}$} & $167.98(6)$ \\
\hline \multicolumn{5}{|c|}{ Hydrogen bonds $\left(\AA\right.$ and $\left.^{\circ}\right)$} \\
\hline $\mathrm{D}-\mathrm{H} \cdots \mathrm{A}$ & D-H & $\mathrm{H} \cdots \mathrm{A}$ & $\mathrm{D} \cdots \mathrm{A}$ & $\mathrm{D}-\mathrm{H} \cdots \mathrm{A}$ \\
\hline $\mathrm{O} 1-\mathrm{H} 11 \cdots \mathrm{S} 1^{\mathrm{iv}}$ & $0.841(13)$ & $2.436(13)$ & $3.2758(13)$ & $176(2)$ \\
\hline $\mathrm{O} 1-\mathrm{H} 12 \cdots \mathrm{S} 2^{\mathrm{v}}$ & $0.846(13)$ & $2.391(13)$ & $3.2285(14)$ & $171(2)$ \\
\hline $\mathrm{O} 2-\mathrm{H} 21 \cdots \mathrm{S} 1^{\mathrm{v}}$ & $0.838(13)$ & $2.478(13)$ & $3.3078(15)$ & $171(2)$ \\
\hline $\mathrm{O} 2-\mathrm{H} 22 \cdots \mathrm{S} 2^{\mathrm{vi}}$ & $0.849(13)$ & $2.439(14)$ & $3.2766(14)$ & $169(2)$ \\
\hline
\end{tabular}

Symmetry codes: (i) $-x, 1-y, 2-z$; (ii) $-x,-y, 2-z$; (iii) $-1-x,-y, 2-z$; (iv) $-1+x, y, z$; (v) $-1+x,-1+y, z$; (vi) $x,-1+y, z$. 


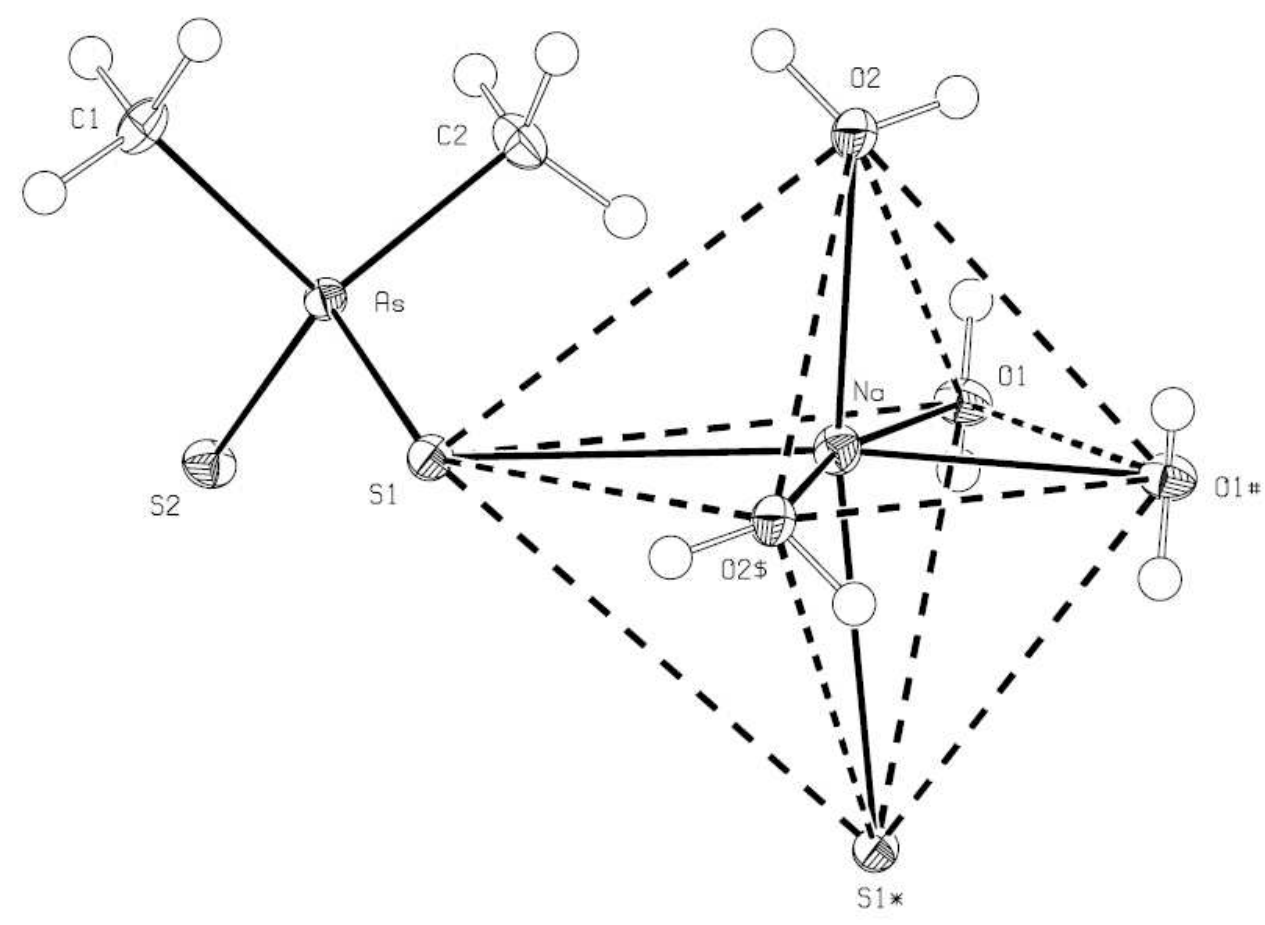

Figure 1. The basic unit of compound $\mathbf{3}$ showing the coordination about the potassium ion (distorted octahedral) and the numbering scheme (thermal ellipsoids at the 50\% probability level).

Symmetry codes: $(*)-x, 1-y,-z ;(\$)-x, 2-y,-z ;$ (\#) $1-x, 2-y,-z$. 


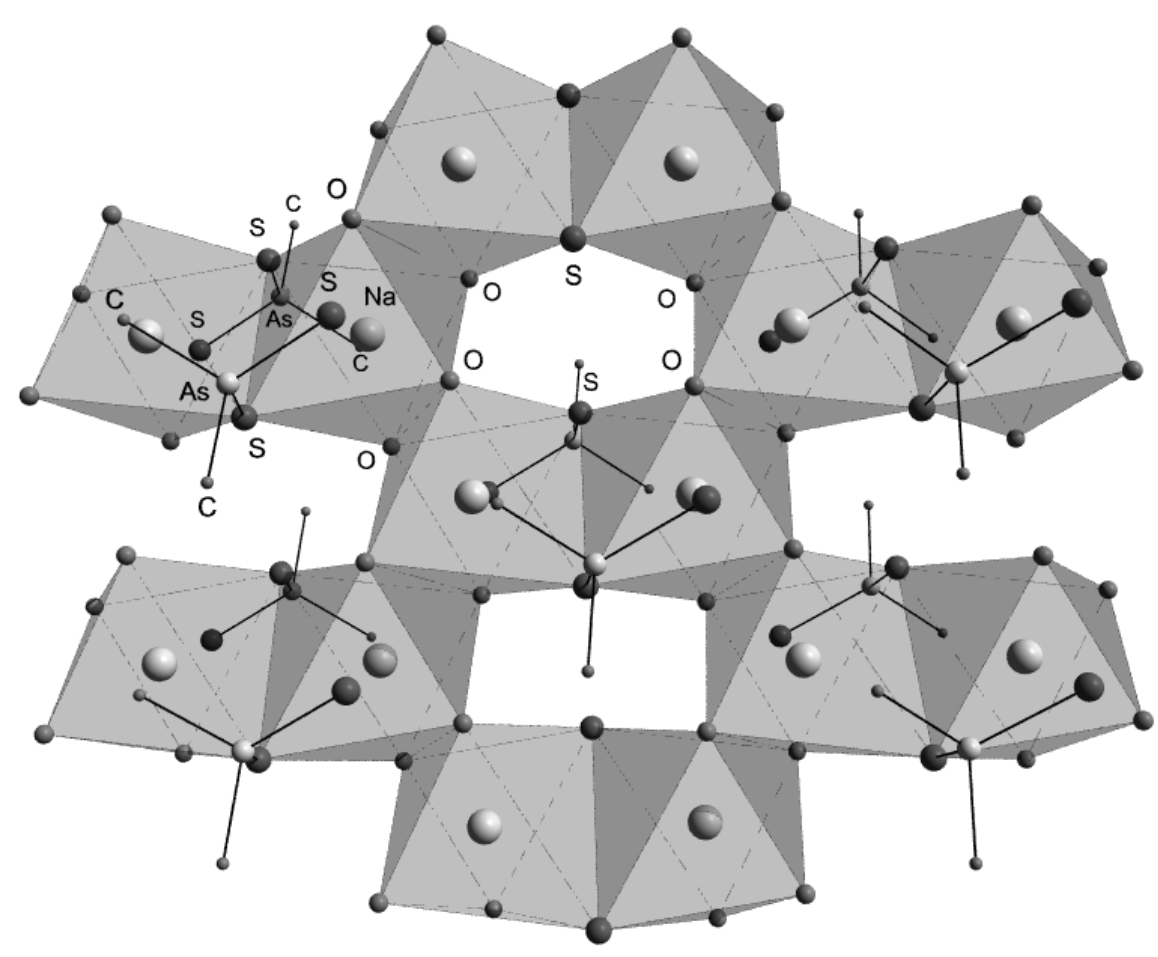

Figure 2. View of the layer structure of 3 in the $a b$ plane showing the $\mathrm{NaO}_{4} \mathrm{~S}_{2}$ octahedra. Hydrogen atoms have been omitted for clarity. The drawing was prepared with the DIAMOND [50] software.

Crystal data, details of data collection and structure refinement are listed in Table 2. Atomic coordinates and thermal displacement parameters are given in Table 3 and selected bond lengths and angles in Table 4. Figure 1 illustrates the molecular structure with the atom numbering scheme. The coordination environment around the arsenic atom in the $\mathrm{Me}_{2} \mathrm{AsS}_{2}$ group is distorted tetrahedral; the S-As-S angle of $114.20(2)^{\circ}$ is noticeably larger and the CAs-C angle of $103.74(9)^{\circ}$, smaller than the tetrahedral angle. The two As-S bonds have similar lengths [2.1435 (5) $\AA$ to S1 and 2.1255 (5) $\AA$ to S2] and are intermediate between a single (ca. 2.21 $\AA$ ) and a double (ca. 2.07 $\AA$ ) bond, implying delocalization of the negative 
charge over the $\mathrm{AsS}_{2}$ moiety of the structure. Similar delocalization has also been observed in similar crystal structures e.g., piperidinium diphenyldithioarsinate [33], potassium dimethyldithioarsinate dihydrate [16], tris(dimethyldithioarsinate)chromium(III) [19], and phenylantimony(III) dimethyldithioarsinate [20]. The fact that $\mathrm{S} 1$ atom is coordinated to $\mathrm{Na}^{+}$ ions while S2 makes no major contacts accounts for the small difference observed among the As-S bonds.

Each sodium ion is surrounded by two sulfur and four water oxygen atoms forming a distorted octahedron in which the sulfurs occupy cis-positions. The deviation from the octahedral geometry is evidenced by the values of trans angles of the polyhedron [166.93 (4) to $\left.171.35(5)^{\circ}\right]$. The ranges of $\mathrm{Na}-\mathrm{S}$ and $\mathrm{Na}-\mathrm{O}$ distances are $2.9267(9)-2.9701(8)$ and 2.3503(14) - 2.4641(16) A, respectively.

The $\mathrm{NaO}_{4} \mathrm{~S}_{2}$ octahedra are linked together by edge-sharing, resulting in the formation of layers in the $a b$ plane with every third octahedron missing, Figure 2. The stability within each layer is enhanced by a network of weak $\mathrm{O}-\mathrm{H} \cdots \mathrm{S}$ bonds involving hydrogens of the two water molecules and the two sulfur atoms (see Table 4). It is noteworthy that the water molecules contribute actively - through coordination and hydrogen bonds - towards the supramolecular organization of the structure. To complete the picture, the $\mathrm{NaO}_{4} \mathrm{~S}_{2}$ octahedra constitute the major part of the structure, while the $\mathrm{Me}_{2} \mathrm{AsS}_{2}$ groups are arranged on either side of each layer. The packing (layer structure) of the present compound $\mathbf{3}$ is very similar to that of sodium diethyldithiophosphinate dihydrate [44] and potassium dimethyldithioarsinate dihydrate [16]. However, the latter structure contains two symmetry-independent potassium ions which have the same atoms coordinated about them but their spatial arrangement is different (the sulfur atoms are at cis and trans positions).

\section{Experimental Section}




\section{General}

Cacodylic acid (Serva), sodium cacodylate trihydrate (Fluka), and sodium sulfide hydrate $\left(\mathrm{Na}_{2} \mathrm{~S} \cdot \mathrm{xH}_{2} \mathrm{O}\right)$ (Ferak) were used. Triphenylphoshine was recrystallized from methanol, m.p. 80-81 ${ }^{\circ}$ C. Palladium(II) acetate (Merck) m.p. $204-206{ }^{\circ} \mathrm{C}$ dec. (lit. [31] $205{ }^{\circ} \mathrm{C}$ ), ${ }^{\mathbf{1}} \mathbf{H}$ NMR $\left(\mathrm{CDCl}_{3}, \mathrm{TMS}\right), \delta: 1.997$ singlet with small singlets at 1.894, 1.972, 2.030, and 2.100, was used without further purification. AR grade solvents were used, while dichloromethane was dried over $\mathrm{A}_{4}$ molecular sieves. $\mathrm{CDCl}_{3}$ and $\mathrm{CD}_{3} \mathrm{OD}$ were not dried nor de-aerated. For experiments under argon, $\mathrm{CD}_{3} \mathrm{OD}$ (C. E. Saclay, Gif-Sur-Yvette, France) packaged under argon was further purged with Ar. Silica gel $60 \mathrm{H}$ (Merck) was used for thin layer chromatography (TLC). Spots on TLCs were made visible by iodine vapours.

IR spectra were obtained on a Perkin-Elmer model 16PC FT-IR spectrometer. ${ }^{1} \mathrm{H}$ NMR (400 $\mathrm{MHz})$ and ${ }^{31} \mathrm{P}$ NMR (162 MHz) spectra were recorded on a DPX Avance Spectrometer in $\mathrm{CDCl}_{3}, \mathrm{CD}_{3} \mathrm{OD}$ or $\left[\mathrm{D}_{6}\right] \mathrm{DMSO}$ with internal TMS (0.000) as standard, $\mathrm{D}_{2} \mathrm{O}$ with DSS (2,2dimethyl-2-silapentane-5-sulfonate, sodium salt) (0.000) as standard while the ${ }^{31} \mathrm{P}$ spectra were referenced to $85 \%$ aqueous $\mathrm{H}_{3} \mathrm{PO}_{4}$ in $\mathrm{D}_{2} \mathrm{O}(0.00 \mathrm{ppm})$. Downfield shifts are positive while upfield shifts are negative in both cases. When needed, the NMR tubes were tumbled on a test tube rotator. Powder X-ray spectrum was recorded on a Siemens powder X-ray diffractometer model D5000. Elemental analyses were obtained through the Center of Instrumental Analyses, University of Patras, Patras, Greece.

Preparation of sodium sulphide pentahydrate, $\mathrm{Na}_{2} \mathrm{~S} \cdot 5 \mathrm{H}_{2} \mathrm{O}$ 
Sodium sulphide nonahydrate, $\mathrm{Na}_{2} \mathrm{~S} \cdot 9 \mathrm{H}_{2} \mathrm{O}$, was obtained from $\mathrm{Na}_{2} \mathrm{~S} \cdot \mathrm{xH}_{2} \mathrm{O}(20 \mathrm{~g})$ and water (10 ml) prewarmed to $50{ }^{\circ} \mathrm{C}$ [45], cooled to $-20{ }^{\circ} \mathrm{C}$ till solidification and then left at $+4{ }^{\circ} \mathrm{C}$ for $1 \mathrm{~h}$. Filtration, washing with absolute ethanol $(1 \times 10 \mathrm{ml})$ and ether, and brief (30 min) drying in vacuum gave the nonahydrate $(8.2 \mathrm{~g})$ as needles, m.p. $52{ }^{\circ} \mathrm{C}$ shrinks but does not melt (lit. [27] $\sim 50{ }^{\circ} \mathrm{C}$ ). By heating and stirring at $100{ }^{\circ} \mathrm{C}$ a quantity of $\mathrm{Na}_{2} \mathrm{~S} \cdot 9 \mathrm{H}_{2} \mathrm{O}$ in a round-bottomed flask connected to a water aspirator gave the expected weight of the pentahydrate as an offwhite solid.

\section{Preparation of sodium dimethyldithioarsinate dihydrate, $\mathrm{Me}_{2} \mathrm{AsS}_{2} \mathrm{Na} \cdot 2 \mathrm{H}_{2} \mathrm{O}$ (3)}

A mixture of Bunsen's cacodyl disulfide $2(548 \mathrm{mg}, 2 \mathrm{mmol})$, sodium sulphide pentahydrate (337 mg, $2 \mathrm{mmol}$ ) and octasulfur (64 mg, $2 \mathrm{mmol}$ sulfur atoms) was grounded and mixed intimately in an agate mortar. The powder was transferred to a flattened-bottom glass evaporating basin preheated at $105{ }^{\circ} \mathrm{C}$. At once a dark yellow mass formed which, in seconds, solidified to an off-white solid. Heating was continued for $3 \mathrm{~h}$ grinding occasionally with a flattened glass rod. To the cooled solid, $95 \%$ ethanol $(15 \mathrm{ml})$ was added, boiled and the hot yellow solution filtered (Pasteur pipette pluged with cotton). Upon cooling, the solution became colorless and crystallized. After overnight cooling at $+4{ }^{\circ} \mathrm{C}$, centrifugation and drying in vacuum gave the salt 3 as white plates (not suitable for X-rays) (642 mg, 70\%), m.p. 222$224{ }^{\circ} \mathrm{C}$ (lit. [9] 181-182 ${ }^{\circ} \mathrm{C},[24]>200{ }^{\circ} \mathrm{C}$ ). Its IR (KBr) spectrum was as published [8]. ${ }^{\mathbf{1}} \mathbf{H}$ NMR $\left(\mathrm{CD}_{3} \mathrm{OD}, \mathrm{TMS}\right), \delta: 1.907(\mathrm{~s}, 6 \mathrm{H}), 4.814\left(\mathrm{~s}, 4 \mathrm{H}\right.$ for $\left.\mathrm{H}_{2} \mathrm{O}\right) ;{ }^{1} \mathbf{H}$ NMR $\left(\mathrm{D}_{2} \mathrm{O}, \mathrm{DSS}\right), \delta$ : 1.993 (s), Table 1.

Preparation

of

palladium(II)

dimethyldithioarsinate

or

bis(dimethyldithioarsinato)palladium(II), $\left(\mathrm{Me}_{2} \mathrm{As} \mathrm{S}_{2}\right)_{2} \mathrm{Pd}(5)$ 
To a vigorously stirred solution of $\mathbf{3}(137 \mathrm{mg}, 0.6 \mathrm{mmol})$ in methanol $(7 \mathrm{ml})$ was added dropwise during $2 \mathrm{~h}$, a solution of palladium(II) acetate (45 mg, $0.2 \mathrm{mmol}$ ) in chloroform (1 $\mathrm{ml})$. The dark brown suspension was stirred at RT for $2 \mathrm{~h}$, centrifuged, washed with methanol (1x2 ml) leaving to settle at RT for $2 \mathrm{~h}$ before centrifuging and dried in vacuum to give the product $5(67.5 \mathrm{mg}, 76 \%)$ as a dark brown powder. It did not melt but decomposed at $\sim 195{ }^{\circ} \mathrm{C}$ giving off $\mathrm{Me}_{2} \mathrm{As}-\mathrm{S}-\mathrm{AsMe}_{2}$ 6. It is insoluble in $\mathrm{Et}_{2} \mathrm{O}$, sparingly soluble in $\mathrm{CHCl}_{3}$ and even less soluble in $\mathrm{MeOH}$ and $\mathrm{Me}_{2} \mathrm{CO}$, and soluble in pyridine giving a dark red solution from which 5 precipitates by adding $\mathrm{Et}_{2} \mathrm{O}$. It keeps tenaciously $\mathrm{AcOH}, \mathrm{MeOH}$, and possibly $\mathrm{H}_{2} \mathrm{O}$ (by ${ }^{1} \mathrm{H}$ NMR) which are removed by keeping it over concentrated sulfuric acid [5] for more than two weeks. $\mathrm{C}_{4} \mathrm{H}_{12} \mathrm{~S}_{4} \mathrm{As}_{2} \mathrm{Pd}\left(M_{\mathrm{r}} 444.64\right)$; C 10.92 (calc. 10.80), H 2.55 (2.72), S 28.40 (28.85)\%. IR (KBr) : 3418 vw, broad, 2982 w, 2090 w, 1610 w, 1394 s, 1250 m, 908 vs, 862 vs, $750 \mathrm{~m}, 596 \mathrm{~s}, 452$ vs. ${ }^{1} \mathbf{H}$ NMR $\left(\mathrm{CDCl}_{3}\right), \delta: 2.212$ (s) and very small singlets at 1.679 and 2.459 ppm; ([D 6$] \mathrm{DMSO}) ; \delta: 2.250 \mathrm{ppm}$, Table 1.

\section{Reaction of $\mathrm{Ph}_{3} \mathrm{P}$ with $\mathrm{Me}_{2} \mathrm{AsS} \mathrm{S}_{2} \mathrm{Na} \cdot 2 \mathrm{H}_{2} \mathrm{O}$ (3) and with $\left(\mathrm{Me}_{2} \mathrm{AsS} \mathrm{S}_{2}\right)_{2} \mathrm{Pd}$ (5)}

In NMR tubes were added $3(50 \mu \mathrm{mol}), \mathrm{Ph}_{3} \mathrm{P}(50 \mu \mathrm{mol})$ and purged with argon. Then, argonpackaged $\mathrm{CD}_{3} \mathrm{OD}(0.6 \mathrm{ml})$ was added in each tube. By shaking for $30 \mathrm{~min}$ the slightly soluble in methanol triphenylphosphine was dissolved and the progress was followed by ${ }^{1} \mathrm{H}$ and ${ }^{31} \mathrm{P}$ NMR for 5 days. Then, dioxygen was admitted and the progress of the oxidation was followed by ${ }^{1} \mathrm{H}$ NMR for another 5 days. Other experiments were conducted without exclusion of air. The results are described in the Results Section. 
To a suspension of $5(45 \mu \mathrm{mol})$ in $\mathrm{CDCl}_{3}(0.6 \mathrm{ml}), \mathrm{Ph}_{3} \mathrm{P}(90 \mu \mathrm{mol})$ was added and shaken for $4 \mathrm{~h}$. A very dark brown solution resulted after $10 \mathrm{~min}$. The results of the ${ }^{1} \mathrm{H}$ NMR analyses are described in the Results Section.

\section{Reaction of $\mathrm{Pd}(\mathrm{OAc})_{2}$ with $\left(\mathrm{Me}_{2} \mathrm{AsS} \mathrm{S}_{2}\right)_{2} \mathrm{Pd}(5)$}

In an NMR tube were added $5(50 \mu \mathrm{mol}), \mathrm{Pd}(\mathrm{OAc})_{2}(50 \mu \mathrm{mol})$ and $\mathrm{CDCl}_{3}(0.6 \mathrm{ml})$ and shaken for $2 \mathrm{~h}$. The pale orange supernatant contained only free acetic acid and traces of $\mathrm{Pd}(\mathrm{OAc})_{2}$. Centrifugation and washing with chloroform gave a supernatant $(3.3 \mathrm{mg}$ of a brownish film) and a black solid (26 mg) having the attributes described in the following experiment.

To a solution of $\mathbf{3}(0.1 \mathrm{mmol})$ in methanol $(1 \mathrm{ml})$ in a centrifuge tube was added dropwise, while stirring, a solution of $\mathrm{Pd}(\mathrm{OAc})_{2}(0.1 \mathrm{mmol})$ in chloroform $(2 \mathrm{ml})$. When half of the $\mathrm{Pd}^{\mathrm{II}}$ has been added a brown suspension of $\mathbf{5}$ was formed which, thereafter, became black. Stirring was continued for $2 \mathrm{~h}$. Centrifugation and washing with methanol $(2 \times 2 \mathrm{ml})$ gave clear colorless supernatants and an amorphous black solid (23.3 mg; expected for equimolar PdS and, e.g., $\left.\mathrm{Me}_{2} \mathrm{As}(\mathrm{O})-\mathrm{S}-\mathrm{Pd}-\mathrm{S}-\mathrm{As}(\mathrm{S}) \mathrm{Me}_{2}: 28.4 \mathrm{mg}\right)$. The black solid did not melt up to $250{ }^{\circ} \mathrm{C}$, and was insoluble in $\mathrm{CHCl}_{3}, \mathrm{Me}_{2} \mathrm{CO}, \mathrm{MeOH}, \mathrm{DMF}$, pyridine, $\mathrm{H}_{2} \mathrm{O}$. For the mixture $\mathrm{PdS} \cdot \mathrm{C}_{4} \mathrm{H}_{12} \mathrm{OSS}_{3} \mathrm{As}_{2} \mathrm{Pd}\left(M_{\mathrm{r}} 138.46+428.57\right) ; \mathrm{C} 9.02$ (calc. 8.47), H 1.85 (2.13), S 21.86 (22.61)\%. IR (KBr) : 2982 w, 2918 mw, 2852 w, 1640 w, 1570 w, 1392 ms, 1244 mw, 906 s, 860 vs, $742 \mathrm{w}, 594 \mathrm{~m}, 454 \mathrm{~m}$. The powder X-ray diffraction spectrum showed two not so strong peaks matching those of $\left(\mathrm{MeOCS}_{2}\right)_{2} \mathrm{Pd}$ and very weak peaks attributable to $\mathrm{PdS}$ (vysotskite) and $\mathrm{Pd}_{16} \mathrm{~S}_{7}$. The black solid suspended in $\mathrm{CHCl}_{3}$ did not react with excess of $\mathbf{2}$, 
nor with $\mathrm{Ph}_{3} \mathrm{P}$ (by TLC [6], ${ }^{1} \mathrm{H}$ and ${ }^{31} \mathrm{P}$ [25] NMR). PdS was also inert towards a chloroform solution of excess 2.

\section{The reaction of Bunsen's cacodyl disulfide (2) with $\mathrm{Pd}(\mathrm{OAc})_{2}$ under various stoichiometries}

In an NMR tube containing a solution of non-equilibrated [22] $2(50 \mu \mathrm{mol})$ in $\mathrm{CDCl}_{3}(0.3 \mathrm{ml})$ was added portion-wise, while shaking the tube, a solution $\mathrm{Pd}(\mathrm{OAc})_{2}(50 \mu \mathrm{mol})$ in $\mathrm{CDCl}_{3}(0.3$ $\mathrm{ml}$ ). At once a very dark brown solution was formed and traces of a black solid appeared. After $24 \mathrm{~h}$ the dark orange supernatant contained, by ${ }^{1} \mathrm{H} \mathrm{NMR}$, free $\mathrm{AcOH}$, some $\mathrm{Pd}(\mathrm{OAc})_{2}$ and unknown compound(s) showing singlets at 1.434 and $2.180 \mathrm{ppm}$. Centrifugation gave the black solid (11.5 $\mathrm{mg})$ having the same attributes as described previously. In a preparative run in dry dichloromethane the sum of the weights of the precipitate and the dried supernatant was less by $2 \mathrm{~mol}$ of $\mathrm{AcOH}$ per mol of $\mathrm{Pd}(\mathrm{OAc})_{2}$ than the sum of the weights of the reactants.

To a solution of non-equilibrated [22] $2(50 \mu \mathrm{mol})$ in $\mathrm{CDCl}_{3}(0.3 \mathrm{ml})$ in an NMR tube was added at once a solution of $\mathrm{Pd}(\mathrm{OAc})_{2}(25 \mu \mathrm{mol})$ in $\mathrm{CDCl}_{3}(0.3 \mathrm{ml})$. A dark orange-red solution was formed and after 5 min the ${ }^{1} \mathrm{H}$ NMR spectrum showed the presence of $\mathbf{1 6}, \mathbf{2}, \mathbf{5}$, 15 with a mole ratio of $1: 0.78: 0.27: 0.14$, free $\mathrm{AcOH}$ plus an unknown molecule resonating at $2.082 \mathrm{ppm}$, and two very small singlets at 1.773 and $1.716 \mathrm{ppm}$. The integration did not change with time. The production of the insoluble $\mathbf{5}$ and its subsequent reaction, the production of 16 (corresponding to $\sim 30 \%$ consumption of 2), and the loss of $2 \mathrm{~mol}$ of $\mathrm{AcOH}$ per mol of $\mathrm{Pd}(\mathrm{OAc})_{2}$ were verified in a preparative run. The ether soluble $\mathbf{1 6}$ was characterized by ${ }^{1} \mathrm{H}$ NMR [7], IR [46] and TLC $\left(\mathrm{Et}_{2} \mathrm{O}\right): R_{\mathrm{f}} 0.40$ [7]. 
Under a 3:1 mole ratio the composition of the solution was again $\mathbf{1 6}, \mathbf{2}, \mathbf{5}, \mathbf{1 5}$ but with a mole ratio of $1: 0.5: 0.12: 0.08$, and it contained free $\mathrm{AcOH}$ plus the unknown compound (singlet at $2.082 \mathrm{ppm})$.

\section{$\mathrm{X}$-ray crystallographic study of $\mathrm{Me}_{2} \mathrm{AsS}_{2} \mathrm{Na} \cdot 2 \mathrm{H}_{2} \mathrm{O}$ (3)}

Needles of $\mathbf{3}$ suitable for X-rays were obtained either by dissolving $\mathbf{3}$ (as white plates) in warm $95 \%$ aqueous ethanol and cooling at $-20{ }^{\circ} \mathrm{C}$ for $3-4$ days or by dissolving 3 in $95 \%$ aqueous ethanol at room temperature, layering ether and, after $2 \mathrm{~h}$, cooling the homogeneous solution at $-20{ }^{\circ} \mathrm{C}$ for $24 \mathrm{~h}$. A colorless prismatic crystal covered with Paraton $\mathrm{N}$ oil was mounted on the tip of a glass capillary. X-ray diffraction data were collected with an Oxford Diffraction Xcalibur diffractometer in $0.6^{\circ}$ increment $\omega$-scans under a flow of nitrogen gas at 100 (2) K with graphite-monochromated MoKa radiation $(\lambda=0.71073 \AA)$. Data collection and reduction were performed with CrysAlis CCD and RED software [47], respectively. The reflection intensities were corrected for absorption by the multi-scan method. The structure was solved by direct methods with SIR92 [48] and refined by full-matrix least-squares on $F^{2}$ using SHELXL-97 [49]. All of the water H-atoms (involved in H-bonding) were located from difference Fourier syntheses and their positions were refined freely with $U_{\text {iso }}(\mathrm{H})$ equal to $1.5 U_{\text {eq }}$ of their parent atoms. The methyl $\mathrm{H}$-atoms were constrained to an ideal geometry [C$\mathrm{H}=0.96 \AA$ and $\left.U_{\text {iso }}(\mathrm{H})=1.5 U_{\text {eq }}(\mathrm{C})\right]$ but were allowed to rotate freely about the C-As bond. The main crystal, collection and structure refinement data are summarized in Table 2.

Supplementary material. Crystallographic data for structure 3 have been deposited with the Cambridge Crystallographic Data Centre as supplementary publication (CCDC 720421). 
Copies of the data can be obtained, free of charge, on application to CCDC, 12 Union Road, Cambridge CB2 1EZ, UK (http://www.ccdc.cam.ac.ck).

Supporting information. Additional colour illustrations of Figures 1 and 2 are available on the WWW as Electronic Supporting Information.

\section{Acknowledgement}

We thank Professor P. G. Koutsoukos, Department of Chemical Engineering, University of Patras, for the powder X-ray spectrum. 


\section{References}

[1] I. Haiduc, D. B. Sowerby, S.-F. Lu, Polyhedron 1995, 14, 23.

[2] I. Haiduc, D. B. Sowerby, Polyhedron 1995, 15, 2469.

[3] I. Haiduc, J. Organomet. Chem. 2001, 623, 29.

[4] J. W. Long, W. J. Ray, Jr., Biochemistry 1973, 12, 3932.

[5] R. Bunsen, Justus Liebigs Ann. Chem. 1843, 46, 1.

[6] P. V. Ioannou, D. G. Vachliotis, T. D. Sideris, Z. Anorg. Allg. Chem. 2007, 633, 2077.

[7] P. V. Ioannou, D. G. Vachliotis, T. D. Sideris, Z. Anorg. Allg. Chem. 2009, 635, 329.

[8] A. T. Casey, N. S. Ham, D. J. Mackey, R. L. Martin, Aust. J. Chem. 1970, 23, 1117.

[9] M. Förster, H. Hertel, W. Kuchen, Angew. Chem. 1970, 82, 842; Angew. Chem. Int. Ed. 1970, 9, 811.

[10] I. Haiduc, L. Silaghi-Dumitrescu, J. Organomet. Chem. 1982, 225, 225.

[11] C. Silvestru, L. Silaghi-Dumitrescu, I. Haiduc, M. J. Bergley, M. Nunn, D. B. Sowerby, J. Chem. Soc. Dalton Trans. 1986, 1031.

[12] L. Silaghi-Dumitrescu, I. Haiduc, J. Organomet. Chem. 1983, 259, 65.

[13] E. W. Abel, M. A. Beckett, P. A. Bates, M. B. Hursthouse, Polyhedron 1988, 7, 1855.

[14] A. T. Casey, J. R. Thackeray, Aust. J. Chem. 1975, 28, 471.

[15] E. Lindner, H.-M. Ebinger, J. Organomet. Chem. 1974, 66, 103.

[16] S. Pascu, L. Silaghi-Dumitrescu, A. J. Blake, I. Haiduc, D. B. Sowerby, Polyhedron 1998, 17,4115 .

[17] R. Cea-Olivares, K. H. Ebert, L. Silaghi-Dumitrescu, I. Haiduc, Heteroatom Chem. 
1997, 8, 137.

[18] L. Silaghi-Dumitrescu, I. Silaghi-Dumitrescu, I. Haiduc, R.-A. Toscano, V. GarcíaMontalvo, R. Cea-Olivares, Z. Anorg. Allg. Chem. 1999, 625, 347.

[19] L. Silaghi-Dumitrescu, A. Haiduc, F. Cervantes-Lee, K. H. Pannell, Rev. Roumaine Chim. 1997, 42, 587.

[20] D. B. Sowerby, M. J. Begley, L. Silaghi-Dumitrescu, I. Silaghi-Dumitrescu, I. Haiduc, J. Organomet. Chem. 1994, 469, 45.

[21] L. Silaghi Dumitrescu, I. Haiduc, J. Weiss, J. Organomet. Chem. 1984, 263, 159.

[22] R. A. Zingaro, K. J. Irgolic, D. H. O’Brien, L. J. Edmonson, Jr., J. Am. Chem. Soc. 1971, 93, 5677.

[23] P. V. Ioannou, G. M. Tsivgoulis, D. G. Vachliotis, Submitted 2009

[24] M. W. Fricke, M. Zeller, H. Sun, V. W.-M. Lai, W. R. Cullen, J. A. Shoemaker, M. R. Witkowski, J. T. Creed, Chem. Res. Toxicol. 2005, 18, 1821.

[25] E. Fluck, H. Binder, Z. Anorg. Allg. Chem. 1967, 354, 139.

[26] J. Y. Andersson, M. Azoulay, J. Chem. Soc., Dalton Trans. 1986, 469.

[27] The Merck Index, Merck and Co., Rahway, N. Jersey, USA, $9^{\text {th }}$ Edition 1976.

[28] K. Mereiter, A. Preisinger, A. Zellner, W. Mikenda, H. Steidl, J. Chem. Soc., Dalton Trans. 1984, 1275.

[29] H. Güler, F. Kurtuluş, I. Kadan, A.Morkan, S. Akin, Phosphorus, Sulfur, and Silicon 2006, $181,1371$.

[30] M. Schmidt, W. Siebert, in: Comprehensive Inorganic Chemistry, J. C. Bailar Jr., H. J. Emeléus, R. Nyholm, A. F. Trotman-Dickenson (eds), Pergamon Press, Oxford, 1973, vol. 2, pp. 817-821.

[31] T. A. Stephenson, S. M. Morehouse, A. R. Powell, J. P. Heffer, G. Wilkinson, J. 
Chem. Soc. 1965, 3632.

[32] A. C. Skapski, M. L. Smart, J. Chem. Soc., Chem. Comm. 1970, 658.

[33] K. Tani, S. Hanabusa, S. Kato, S. Mutoh, S. Suzuki, M. Ishida, J. Chem. Soc., Dalton Trans. 2001, 518.

[34] a) K. T. Suzuki, B. K. Mandal, A. Katagiri, Y. Sakuma, A. Kawakami, Y. Ogra, K. Yamaguchi, Y. Sei, K. Yamanaka, K. Anzai, M. Ohmichi, Chem. Res. Toxicol. 2004, 17, 914; b) H. Naranmandura, N. Suzuki, K. T. Suzuki, Chem. Res. Toxicol. 2006, $19,1010$.

[35] R. K. Harris, R. G. Hayter, Can. J. Chem. 1964, 42, 2282.

[36] H. J. Emeléus, R. N. Haszeldine, E. G. Walaschewski, J. Chem. Soc. 1953, 1552.

[37] G. O. Doak, L. D. Freedman, Organometallic Compounds of Arsenic, Antimony, and Bismuth, Wiley, New York, 1970, pp. 122-123.

[38] F. F. Blicke, F. D. Smith, J. Am. Chem. Soc. 1929, 51, 2272.

[39] D. F. Steele, T. A. Stephenson, J. Chem. Soc., Dalton Trans. 1973, 2124.

[40] J. P. Fackler, Jr., L. D. Thompson, I. J. B. Lin, T. A. Stephenson, R. O. Gould, J. M. C. Alison, A. J. F. Fraser, Inorg. Chem. 1982, 21, 2379 and references therein.

[41] P. Aslanidis, F. Kober, Chemiker-Ztg. 1988, 112, 106.

[42] T. F. Blackburn, J. Schwartz, J. Chem. Soc., Chem. Comm. 1977, 157.

[43] J. T. Bagdanoff, B. M. Stoltz, Angew. Chem. Int. Ed. 2004, 43, 353.

[44] G. Svensson, J. Albertsson, Acta Crystallogr. 1989, C45, 395.

[45] H. Remy, Treatise on Inorganic Chemistry, translated by J. S. Anderson, Elsevier, 1956, volume I, p. 735.

[46] L. Silaghi-Dumitrescu, S. Pascu, I. Silaghi-Dumitrescu, I. Haiduc, M. N. Gibbons, D. B. Sowerby, J. Organomet. Chem. 1997, 549, 187. 
[47] Oxford Diffraction, CrysAlis CCD and CrysAlis RED, Version 1.171.32.15, Oxford Diffraction Ltd, Abingdon, Oxford, England, 2008.

[48] M. C. Burla, M. Camalli, B. Carrozzini, G. L. Cascarano, C. Giacovazzo, G. Polidori, R. Spagna, J. Appl. Cryst. 2003, 36, 1103.

[49] G. M. Sheldrick, SHELXL-97. Program for Crystal Structure Analysis. Univ. of Göttingen: Göttingen, Germany, 1997.

[50] K. Brandenburg, DIAMOND. Program for Crystal and Molecular Structure Visualization, Release 3.1f, Crystal Impact GbR, Bonn, Germany, 2008. 


\section{Legends to Figures}

Figure 1. The basic unit of compound $\mathbf{3}$ showing the coordination about the potassium ion (distorted octahedral) and the numbering scheme (thermal ellipsoids at the 50\% probability level).

Symmetry codes: $(*)-x, 1-y,-z ;(\$)-x, 2-y,-z ;$ (\#) 1-x, 2-y, $-z$.

Figure 2. View of the layer structure of 3 in the $a b$ plane showing the $\mathrm{NaO}_{4} \mathrm{~S}_{2}$ octahedra. Hydrogen atoms have been omitted for clarity. The drawing was prepared with the DIAMOND [50] software. 